\title{
Job burnout syndrome and stress coping strategies of academic students
}

\begin{abstract}
Introduction. People focused on helping others in their daily professional career are especially exposed to stress. The inability to relieve stress is a common cause of the burnout syndrome. It turns out that also college students, who are prepared to work with people, are exposed to the job burnout syndrome, even during their education process. The possible cause might be unfamiliarity with effective stress coping methods or inability to use them properly.

Aim. The aim of this paper is to study job burnout syndrome and stress coping strategies among students of selected academic majors, and also to analyze relations and differences between these results.

Material and methods. The research has been conducted among 141 fifth or sixth-year students of nursing, medicine and pedagogy in Krakow. The study was based on surveys: a questionnaire made by the author, The Maslach Burnout Inventory (MBI) and The Coping Inventory for Stressful Situations (CISS).

Results. The analysis of obtained results has showed that there is a significant difference between stress coping strategies among examined students and that there is a relation between job burnout syndrome and students' academic majors. There is also a relation between job burnout and stress coping strategies among students of selected academic majors. However, there is no relationship between job burnout and students' selected academic majors.

Conclusions. There is also a relationship between students' stress coping strategies and selected academic majors and burnout syndrome.
\end{abstract}

Keywords: job burnout, stress, coping strategies.

DOI: $10.12923 / \mathrm{j} .0044-2011 / 123-3 / \mathrm{a} .07$

\section{INTRODUCTION}

Choosing any occupation is one of the most important decisions in life. However, young people often are not aware what kind of decision they are making, because they do not know what their chosen occupation involves. There are many factors, which contribute to choosing future occupation: one can be motivated by high income, prestige or just the willing to help other people. Some academic specializations, especially medical, nursing or pedagogy, are focused on preparing future specialists to work with people who are both healthy and sick. However, it happens often that during academic education or practice, understood as few internships, reality does not meet one's expectations resulting in disappointment. It may lead to frustration, dissatisfaction and stress that build up constantly. The situation can even become worse by ignoring effective stress coping strategies and their implementation, what consequently may lead to job burnout.

American social psychologist, Christina Maslach, describes definition of job burnout as an answer of the human body to constant stress, which has a direct relation with one's job [1].
Job burnout usually is connected with people whose job involves helping other people. Maslach develops a multidimensional model in which she explains syndromes which signify job burnout such as:

- emotional exhaustion - a feeling of extreme exhaustion and aversion towards one's job. Oversensitivity and irritation occur along with some psychosomatic syndromes such as headaches or insomnia.

- depersonalization - relations with others become impersonal and are characterized by considerable amount of distance and reservation toward patients / customers and also the lack of compassion and empathy.

- a diminished sense of personal accomplishment - experiencing a low sense of efficacy at work; lost faith in one's capacity to resolve problems and also low self-esteem regarding one's competence [2].

R.S. Lazarus is a founder of the psychological conception of stress. He claims that one's personal judgement, interpretation and reaction to a particular event amount to origin of stress. It means that a situation that triggers stress is not as important as its interpretation.

${ }^{1}$ Health Psychology Department of the Faculty of Psychology

and Humanities of the Kraków University of Andrzej Frycz Modrzewski, Poland

${ }^{2}$ Faculty of Health of the Jagiellonian University of Collegium Medicum in Kraków, Poland 
A person may be stressed when he or she reads a particular situation as something what goes beyond his or her coping strategies [3].

"Coping" with stress is a strategy, which relates to the whole action performed by a particular person in a situation he or she finds stressful. There are specific forms of behaviour attributed to a particular person in a situation, which she or he reads as stressful [4].

Below there are stress coping strategies distinguished by Endler and Parker:

- concentration on task - identifying a problem, assessing a possible solution and applying appropriate strategies which may resolve a particular situation

- concentration on emotions - acting in a way that is supposed to reduce emotional tension. A person focuses entirely on himself or herself, his or her own feelings and emotions trying to improve his or her mood by fantasying or thinking wishfully instead of solving a real problem

- concentration on avoidance - avoiding thinking about a stressful situation or relieving it. A person does not perform any actions which may solve a stressful situation $[5,6]$.

\section{AIM}

The aim of this paper is to study job burnout and stress coping strategies among students of selected academic specializations, and to analyze relations and differences between studied variables.

\section{Study issues, formulated as study questions, are:}

1. Are there any syndromes of job burnout among examined students?

2. Is there any difference in stress coping strategies among examined students?

3. Is there any relation between job burnout and one's academic major?

4. Is there any relation between stress coping strategies and one's academic major?

5. Is there any relation between job burnout and stress coping strategies among students of selected academic majors?

\section{Study hypotheses:}

1. There is a difference in stress coping strategies among examined students.

2. There is a relation between job burnout and one's academic specialization.

3. There is a relation between stress-coping strategies and one's academic major.

4. There is a relation between job burnout and stress coping strategies among students of selected academic majors.

\section{MATERIAL AND METHODS}

The study was conducted in March/April 2010 among full-time students from various universities in Kraków. The total number of examined senior M.A. students amounts to 141 including 47 nursing and pedagogy students and 47 medical students.
The study is based on an opinion poll in the form of a survey. Other study tools used are:

1. Questionnaire made by the author - consisting of 10 study questions and some socio-demographic questions. Most questions are free response, but there are 4 closed questions (with only one answer to be chosen) and 1 semi-free response question. Questions were re-lated to job burnout and source of stress during studies among examined students.

2. The Maslach Burnout Inventory Questionnaire (MBI) a self-report questionnaire consist-ing of 22 statements about one's feelings. Statements are divided into three categories which relate to stages of job burnout. Ten statements are related to emotional exhaustion, 5 to depersonalization and 8 to a diminished sense of personal accomplishment. The answers are stated with a sevendegree scale according to how often one experiences a particular feeling (from "never" to "every day").

3. N.S. Endler's and J.D.A. Parker's Coping Inventory for Stressful Situations (CISS) - de-fines stress coping strategies in difficult and stressful situations among examined students. The questionnaire consists of 49 statements, which describe various forms of behaviour in difficult and stressful situations. Examined students answer, according to a five-degree scale, how often they behave in a particular way during some stressful situation. Statistical analysis is carried out using Statistica 7.1 programme. All statistical calculations are conducted ac-cording to p-value that does not exceed 0.05. Calculations are based on tests by Shapiro-Wilk, Spearman and Kruskal-Wallis.

\section{RESULTS}

All examined students generally state academic professors' negligent attitude as the main reason for negligent job burnout during studies $(28.6 \%)$; this is claimed by $33.3 \%$ of medical students, $32.0 \%$ of nursing students and $23.1 \%$ of pedagogy students (Table 1). Pedagogy students believe that the lack of practice is the main reason for job burnout (17.6\%), but for some nursing students $(28 \%)$ too much practice is the reason for job burnout. Some medical students $(25.9 \%)$ and pedagogy students $(5.1 \%)$ complain about having no free time, too much to learn and too many duties. For some medical students $(7.4 \%)$ and pedagogy students $(2.6 \%)$ another reason for job burnout occurring during studies may be exhaustion. Also, unpleasant experience during practice may be the reason for job burnout for some nursing stu-dents (16.0\%) and pedagogy students (2.6\%). Moreover, some pedagogy students $(12.8 \%)$ state disappointment by their academic program and the clash between their expectations and reality as the reason for job burnout. Some medical students $(7.4 \%)$ and pedagogy students $(2.6 \%)$ complain about bad working conditions and negative opinions of their occupation ex-pressed by media. Another complaint issued by medical students $(7.4 \%)$ concerns their studies which they assess as taking too long to complete and not being challenging enough. 
TABLE 1. Job burnout sources during the study time stated by students.

\begin{tabular}{|c|c|c|c|c|c|c|c|c|c|}
\hline \multirow[t]{2}{*}{ No. } & \multirow{2}{*}{$\begin{array}{c}\text { Answers } \\
\text { indicated } \\
\text { by students }\end{array}$} & \multicolumn{2}{|c|}{$\begin{array}{l}\text { Medical } \\
\text { students }\end{array}$} & \multicolumn{2}{|c|}{$\begin{array}{l}\text { Nursing } \\
\text { students }\end{array}$} & \multicolumn{2}{|c|}{$\begin{array}{l}\text { Pedagogy } \\
\text { students }\end{array}$} & \multicolumn{2}{|c|}{ Total } \\
\hline & & $\mathrm{N}$ & $\%$ & $\mathrm{~N}$ & $\%$ & $\mathrm{~N}$ & $\%$ & $\mathrm{~N}$ & $\%$ \\
\hline 1. & $\begin{array}{l}\text { Professors' } \\
\text { negligent } \\
\text { attitude }\end{array}$ & 9 & 33.3 & 8 & 32.0 & 9 & 23.1 & 26 & 28.6 \\
\hline 2. & $\begin{array}{c}\text { Lack of practice, } \\
\text { lots of theory }\end{array}$ & 0 & 0.0 & 0 & 0.0 & 16 & 41.0 & 16 & 17.6 \\
\hline 3. & $\begin{array}{l}\text { No free time, } \\
\text { too much to learn, } \\
\text { too many duties }\end{array}$ & 7 & 25.9 & 0 & 0.0 & 2 & 5.1 & 9 & 9.9 \\
\hline 4. & $\begin{array}{c}\text { Large number } \\
\text { of practice hours }\end{array}$ & 0 & 0.0 & 7 & 28.0 & 0 & 0.0 & 7 & 7.7 \\
\hline 5. & Exhaustion & 2 & 7.4 & 3 & 0.0 & 1 & 2.6 & 6 & 6.6 \\
\hline 6. & $\begin{array}{c}\text { Unpleasant } \\
\text { experience } \\
\text { during practice }\end{array}$ & 0 & 0.0 & 4 & 16.0 & 1 & 2.6 & 5 & 5.5 \\
\hline 7. & $\begin{array}{c}\text { Academic } \\
\text { program } \\
\text { disappointment }\end{array}$ & 0 & 0.0 & 0 & 0.0 & 5 & 12.8 & 5 & 5.5 \\
\hline 8. & $\begin{array}{c}\text { Bad working } \\
\text { conditions } \\
\text { and negative } \\
\text { opinion expressed } \\
\text { by media }\end{array}$ & 2 & 7.4 & 0 & 0.0 & 1 & 2.6 & 3 & 3.3 \\
\hline 9. & $\begin{array}{c}\text { Long-time } \\
\text { studies with no } \\
\text { challenges }\end{array}$ & 2 & 7.4 & 0 & 0.0 & 0 & 0.0 & 2 & 2.2 \\
\hline 10. & Others & 3 & 11.1 & 2 & 7.4 & 4 & 14.8 & 9 & 9.9 \\
\hline 11. & No answer & 2 & 7.4 & 1 & 4.0 & 0 & 0.0 & 3 & 3.3 \\
\hline
\end{tabular}

TABLE 2. Stress sources during the studies stated by students.

\begin{tabular}{|c|c|c|c|c|c|c|c|c|c|}
\hline \multirow{2}{*}{ No. } & \multirow{2}{*}{$\begin{array}{c}\text { Answers } \\
\text { indicated } \\
\text { by students }\end{array}$} & \multicolumn{2}{|c|}{$\begin{array}{l}\text { Medical } \\
\text { students }\end{array}$} & \multicolumn{2}{|c|}{$\begin{array}{l}\text { Nursing } \\
\text { students }\end{array}$} & \multicolumn{2}{|c|}{$\begin{array}{c}\text { Pedagogy } \\
\text { students }\end{array}$} & \multicolumn{2}{|c|}{ Total } \\
\hline & & $\mathrm{N}$ & $\%$ & $\mathrm{~N}$ & $\%$ & $\mathrm{~N}$ & $\%$ & $\mathrm{~N}$ & $\%$ \\
\hline 1. & Exams and tests & 30 & 63.8 & 20 & 42.6 & 13 & 27.7 & 63 & 44.7 \\
\hline 2. & $\begin{array}{c}\text { Professors' } \\
\text { negligent attitude } \\
\text { and their unclear } \\
\text { requirements }\end{array}$ & 6 & 12.8 & 15 & 31.9 & 9 & 19.1 & 30 & 21.3 \\
\hline 3. & $\begin{array}{c}\text { Unreasonable } \\
\text { requirements } \\
\text { beyond students } \\
\text { capabilities }\end{array}$ & 7 & 14.9 & 0 & 0.0 & 4 & 8.5 & 11 & 7.8 \\
\hline 4. & $\begin{array}{l}\text { Lecture- } \\
\text { conducting } \\
\text { and speech- } \\
\text { giving }\end{array}$ & 0 & 0.0 & 0 & 0.0 & 7 & 14.9 & 7 & 5.0 \\
\hline 5. & $\begin{array}{l}\text { Professional } \\
\text { practice }\end{array}$ & 0 & 0.0 & 8 & 17.0 & 0 & 0.0 & 8 & 5.7 \\
\hline 6. & $\begin{array}{c}\text { Writing } \\
\text { and defending } \\
\text { M.A. thesis }\end{array}$ & 0 & 0.0 & 0 & 0.0 & 4 & 8.5 & 4 & 2.8 \\
\hline 7. & $\begin{array}{c}\text { Lack } \\
\text { of free time }\end{array}$ & 1 & 2.1 & 1 & 2.1 & 2 & 4.3 & 4 & 2.8 \\
\hline 8. & $\begin{array}{l}\text { Thoughts } \\
\text { about future }\end{array}$ & 0 & 0.0 & 0 & 0.0 & 4 & 8.5 & 4 & 2.8 \\
\hline 9. & $\begin{array}{c}\text { Lack } \\
\text { of money }\end{array}$ & 0 & 0.0 & 0 & 0.0 & 2 & 4.3 & 2 & 1.4 \\
\hline 10. & Others & 3 & 6.3 & 1 & 2.1 & 2 & 4.2 & 6 & 4.3 \\
\hline 11. & No answer & 0 & 0.0 & 2 & 4.3 & 0 & 0.0 & 2 & 1.4 \\
\hline
\end{tabular}

The most stressful situation for the examined students $(44.7 \%)$ were exams and tests; this was stated by $63.8 \%$ of medical students, $42.6 \%$ of nursing students and $27.7 \%$ of pedagogy students (Table 2). Academic professors' negligent attitude and their unclear require-ments is another stress stimulus for $21.3 \%$ of nursing students, $12.8 \%$ of medical students and $19.1 \%$ of pedagogy students. There are claims about requirements being unreasonable and beyond one's capacity expressed by $14.9 \%$ of medical students and $8.5 \%$ of pedagogy stu-dents. Conducting a lecture and giving a speech is a stressful situation for $14.9 \%$ of pedagogy students. Practice is stressful for $17.0 \%$ of nursing students; $8.5 \%$ of pedagogy students find stressful writing and defending M.A. thesis. The lack of free time is also stressful to $4.3 \%$ of pedagogy students and $2.1 \%$ of medical and nursing students. Thoughts about future are terri-fying and stressful for $8.5 \%$ of pedagogy students, but medical and nursing students do not indicate this. The lack of money is stressing for $4.3 \%$ of pedagogy students.

\section{The analysis of a difference between various stress coping strategies among examined students}

Medical students usually choose concentration on task as their stress coping strategy (Figure1a). On the other hand, stress coping strategies, which concentrate on emotions and avoidance, are rather rare as they occur on similar levels.

The most common stress coping strategy for nursing students is concentration on task (Figurelb). Concentration on emotion and avoidance are rarely enforced, because they are on similar levels.

Stress coping strategy, which concentrates on avoidance, is the most rare among peda-gogy students as it has the lowest value (Figure 1c). Pedagogy students most often employ

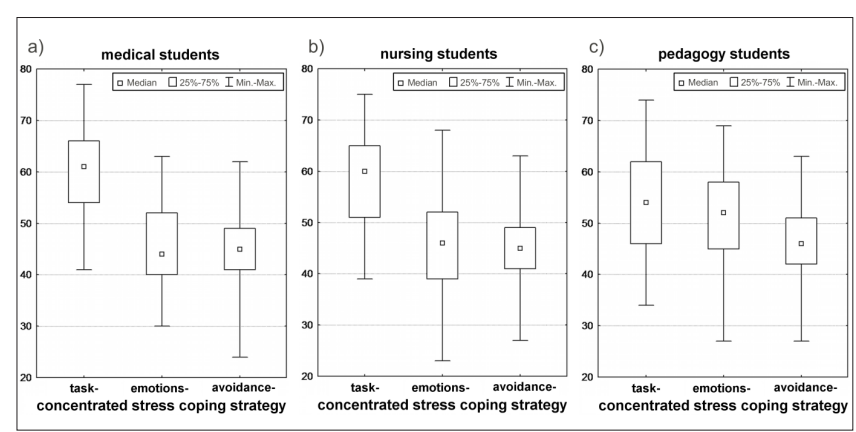

FIGURE 1. Graphical interpretation of Kruskal-Wallis rank test for stress coping strategies among medical, nursing and pedagogy students.

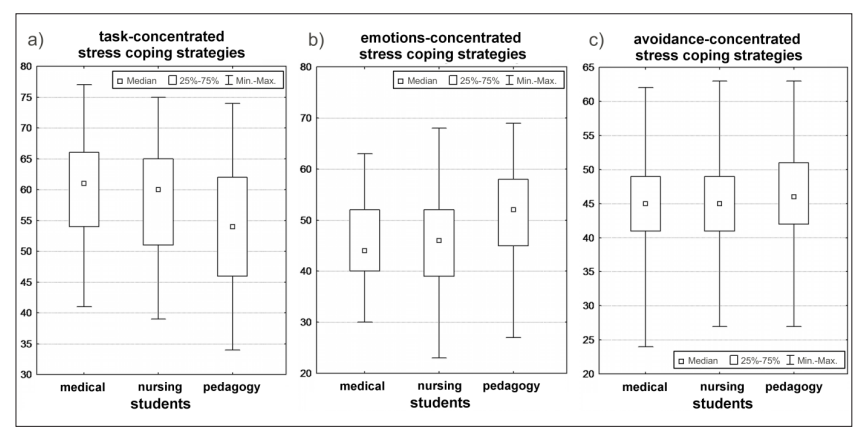

FIGURE 2. Graphical interpretation of Kruskal-Wallis rank test for job burnout elements among medical, nursing and pedagogy students. 
concentration on emotions and task as their stress coping strategies, because they both are on similar levels.

The analysis of a relation between job burnout and academic specialization

Regardless of the academic specialization, emotional exhaustion is on similar level among medical, nursing and pedagogy students (Figure 2a).

There is a higher level of depersonalization among pedagogy students than among medical and nursing students (Figure $2 b$ ). There is less indication of a diminished sense of personal accomplishment among pedagogy students than medical and nursing students (Figure 2c).

\section{The analysis of a relation between stress coping strategy} and academic specialization

Pedagogy students have less indication of concentration on task as stress coping strat-egy than medical and nursing students (Figure 3a). Pedagogy students more often use concen-tration on emotion as their stress coping strategy than medical and nursing students (Figure $3 b$ ).

Regardless of academic specialization, avoidance as stress coping strategy occurs on similar level (Figure 3c).

The analysis of a relation between job burnout and stress coping strategy among exam-ined students of selected academic specializations

Spearman's rank, indicates the presence of vital statistical positive correlation between emotional exhaustion and stress coping strategy such as concentration on emotions (Table 3) the higher level of emotional exhaustion occurs among medical students the more frequently they employ stress coping strategy that is concentration on emotions. The same result is ob-tained by comparing depersonalization with stress coping strategy that is concentration on emotions; opposite relation is indicated by comparing a diminished sense of personal accom-plishment with stress coping strategy that is concentration on task.

Spearman's rank among examined students also indicates the presence of vital statisti-cal positive correlation between a diminished sense of personal accomplishment and stress coping strategy that is concentration on emotions - the higher level of failure in personal ac-complishment medical students have, the higher level of concentration on emotions they have as their stress coping strategy.

In other comparisons, Spearman's rank correlation does not indicate vital statistical positive correlation between studied variable among medical students.

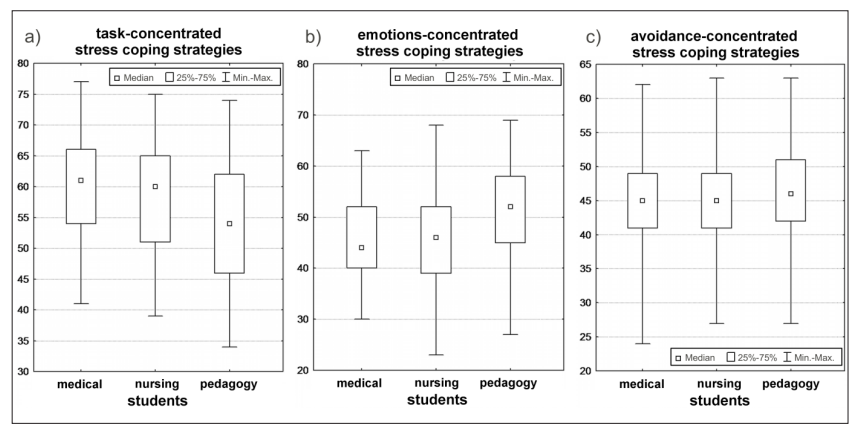

FIGURE 3. Graphical interpretation of Kruskal-Wallis rank test for stress coping strategies among medical, nursing and pedagogy students.
TABLE 3. Spearmans' rank-order correlation - analysis of stress coping strategies and job burnout among medical students.

\begin{tabular}{lcccc}
\hline \hline \multirow{1}{*}{$\begin{array}{c}\text { Variables pair } \\
\text { (medical students) }\end{array}$} & $\begin{array}{c}\text { Pair-removed BD Spearmans' } \\
\text { rank-order correlation } \\
\text { Correlations with p }<0.050 \\
\text { are marked in bold }\end{array}$ \\
\cline { 2 - 5 } & $\mathrm{N}$ & $\begin{array}{c}\mathrm{R} \\
\text { Spear. }\end{array}$ & $\mathrm{t}$ (N-2) & p-level \\
\hline $\begin{array}{l}\text { emotional exhaustion/task-concentrated } \\
\text { stress coping strategies }\end{array}$ & 47 & -0.232 & -1.603 & 0.116 \\
\hline $\begin{array}{l}\text { emotional exhaustion/emotions- } \\
\text { concentrated stress coping strategies }\end{array}$ & 47 & $\mathbf{0 . 6 3 3}$ & $\mathbf{5 . 4 8 2}$ & $\mathbf{0 . 0 0 0}$ \\
\hline $\begin{array}{l}\text { emotional exhaustion/avoidance- } \\
\text { concentrated stress coping strategies }\end{array}$ & 47 & 0.032 & 0.215 & 0.831 \\
\hline $\begin{array}{l}\text { depersonalization/task-concentrated } \\
\text { stress coping strategies }\end{array}$ & 47 & 0.047 & 0.314 & 0.755 \\
\hline $\begin{array}{l}\text { depersonalization/emotions- } \\
\text { concentrated stress coping strategies }\end{array}$ & 47 & $\mathbf{0 . 3 3 3}$ & $\mathbf{2 . 3 7 1}$ & $\mathbf{0 . 0 2 2}$ \\
\hline $\begin{array}{l}\text { depersonalization/avoidance- } \\
\text { concentrated stress coping strategies }\end{array}$ & 47 & 0.285 & 1.998 & 0.052 \\
\hline $\begin{array}{l}\text { diminished sense of personal } \\
\text { accomplishment*/task-concentrated } \\
\text { stress coping strategies }\end{array}$ & 47 & $\mathbf{0 . 5 2 6}$ & $\mathbf{4 . 1 5 1}$ & $\mathbf{0 . 0 0 0}$ \\
\hline $\begin{array}{l}\text { diminished sense of personal } \\
\text { accomplishment*/emotions- } \\
\text { concentrated stress coping strategies }\end{array}$ & 47 & $\mathbf{- 0 . 5 3 1}$ & $\mathbf{- 4 . 2 0 2}$ & $\mathbf{0 . 0 0 0}$ \\
\hline $\begin{array}{l}\text { diminished sense of personal } \\
\text { accomplishment*/avoidance- } \\
\text { concentrated stress coping strategies }\end{array}$ & 47 & -0.149 & -1.009 & 0.318 \\
\hline
\end{tabular}

* for variable labeled "diminished sense of personal accomplishment" reverse scale is used, thus the correlation sign should be changed while interpreting the data

TABLE 4. Spearmans' rank-order correlation - analysis of stress coping strategies and job burnout among nursing students.

\begin{tabular}{llccc}
\hline \hline \multirow{1}{*}{$\begin{array}{c}\text { Variables pair } \\
\text { (nursing students) }\end{array}$} & $\begin{array}{c}\text { Pair-removed BD Spearmans' } \\
\text { rank-order correlation } \\
\text { Correlations } \\
\text { are mith p }<0.050\end{array}$ \\
\cline { 2 - 6 } & $\mathrm{N}$ & $\begin{array}{c}\mathrm{R} \\
\text { Spear. }\end{array}$ & $\mathrm{t}(\mathrm{N}-2)$ & p-level \\
\hline $\begin{array}{l}\text { emotional exhaustion/task-concentrated } \\
\text { stress coping strategies }\end{array}$ & 47 & $\mathbf{- 0 . 4 0 2}$ & $\mathbf{- 2 . 9 4 9}$ & $\mathbf{0 . 0 0 5}$ \\
\hline $\begin{array}{l}\text { emotional exhaustion/emotions- } \\
\text { concentrated stress coping strategies }\end{array}$ & 47 & $\mathbf{0 . 4 5 2}$ & $\mathbf{3 . 4 0 2}$ & $\mathbf{0 . 0 0 1}$ \\
\hline $\begin{array}{l}\text { emotional exhaustion/avoidance- } \\
\text { concentrated stress coping strategies }\end{array}$ & 47 & 0.229 & 1.580 & 0.121 \\
\hline $\begin{array}{l}\text { depersonalization/task-concentrated } \\
\text { stress coping strategies }\end{array}$ & 47 & $\mathbf{- 0 . 3 6 0}$ & $\mathbf{- 2 . 5 8 9}$ & $\mathbf{0 . 0 1 3}$ \\
\hline $\begin{array}{l}\text { depersonalization/emotions- } \\
\text { concentrated stress coping strategies }\end{array}$ & 47 & $\mathbf{0 . 3 1 1}$ & $\mathbf{2 . 1 9 7}$ & $\mathbf{0 . 0 3 3}$ \\
\hline $\begin{array}{l}\text { depersonalization/avoidance- } \\
\text { concentrated stress coping strategies }\end{array}$ & 47 & 0.096 & 0.645 & 0.523 \\
\hline $\begin{array}{l}\text { diminished sense of personal } \\
\text { accomplishment*/task-concentrated } \\
\text { stress coping strategies }\end{array}$ & 47 & $\mathbf{0 . 4 4 7}$ & $\mathbf{3 . 3 5 5}$ & $\mathbf{0 . 0 0 2}$ \\
\hline $\begin{array}{l}\text { diminished sense of personal } \\
\text { accomplishment*/emotions- } \\
\text { concentrated stress coping strategies }\end{array}$ & 47 & -0.220 & -1.509 & 0.138 \\
\hline $\begin{array}{l}\text { diminished sense of personal } \\
\text { accomplishment*/avoidance- } \\
\text { concentrated stress coping strategies }\end{array}$ & 47 & 0.136 & 0.923 & 0.361 \\
\hline
\end{tabular}

* for variable labeled "diminished sense of personal accomplishment" reverse scale is used, thus the correlation sign should be changed while interpreting the data 
Spearman's rank shows the presence of vital statistical positive correlation between emotional exhaustion and stress coping strategy that is concentration on emotions among nursing students (Table 4) - the higher level of emotional exhaustion nursing students have, the more often they employ stress coping strategy that is concentration on emotions. The same result is obtained by comprising depersonalization with stress coping strategy that is concen-tration on emotions; opposite relation is obtained by comparing a diminished sense of personal accomplishment and stress coping strategy that is concentration on task.

Spearman's rank regarding studied pairs indicates the presence of vital statistical nega-tive correlation between emotional exhaustion and stress coping strategy that is concentration on task; the higher level of failure in personal accomplishment nursing students have, the higher level of concentration on task they have as their stress coping strategy. The same result is obtained by comparing depersonalization with stress coping strategy that is concentration on task.

Spearman's rank does not signal the presence of vital statistical correlation between studied variable among nursing students. Spearman's rank indicates vital statistical positive correlation between emotional exhaustion and stress coping strategy that is concentration on emotions among pedagogy students (Table 5); the higher level of emotional exhaustion peda-gogy students have, the more often they employ stress coping strategy that is concentration on emotions. The same result is obtained by comparing depersonalization with stress coping strategy that is concentration on emotions

TABLE 5. Spearmans' rank-order correlation - analysis of stress coping strategies and job burnout among pedagogy students.

\begin{tabular}{lcccc}
\hline \hline \multirow{1}{*}{$\begin{array}{l}\text { Variables pair } \\
\text { (pedagogy students) }\end{array}$} & $\begin{array}{c}\text { Pair-removed BD Spearmans' } \\
\text { rank-order correlation } \\
\text { Correlations } \begin{array}{c}\text { with p }<0.050 \\
\text { are marked in bold }\end{array}\end{array}$ \\
\cline { 2 - 5 } & $\mathrm{N}$ & $\begin{array}{c}\mathrm{R} \\
\text { Spear. }\end{array}$ & $\mathrm{t}$ (N-2) & p-level \\
\hline $\begin{array}{l}\text { emotional exhaustion/task-concentrated } \\
\text { stress coping strategies }\end{array}$ & 47 & -0.135 & -0.916 & 0.365 \\
\hline $\begin{array}{l}\text { emotional exhaustion/emotions- } \\
\text { concentrated stress coping strategies }\end{array}$ & 47 & $\mathbf{0 . 5 8 8}$ & $\mathbf{4 . 8 7 5}$ & $\mathbf{0 . 0 0 0}$ \\
\hline $\begin{array}{l}\text { emotional exhaustion/avoidance- } \\
\text { concentrated stress coping strategies }\end{array}$ & 47 & 0.117 & 0.793 & 0.432 \\
\hline $\begin{array}{l}\text { depersonalization/task-concentrated } \\
\text { stress coping strategies }\end{array}$ & 47 & -0.151 & -1.021 & 0.313 \\
\hline $\begin{array}{l}\text { depersonalization/emotions- } \\
\text { concentrated stress coping strategies }\end{array}$ & 47 & $\mathbf{0 . 4 1 1}$ & $\mathbf{3 . 0 2 0}$ & $\mathbf{0 . 0 0 4}$ \\
\hline $\begin{array}{l}\text { depersonalization/avoidance- } \\
\text { concentrated stress coping strategies }\end{array}$ & 47 & $\mathbf{0 . 3 2 6}$ & $\mathbf{2 . 3 1 5}$ & $\mathbf{0 . 0 2 5}$ \\
\hline $\begin{array}{l}\text { diminished sense of personal } \\
\text { accomplishment*/task-concentrated } \\
\text { stress coping strategies }\end{array}$ & 47 & $\mathbf{0 . 5 6 7}$ & $\mathbf{4 . 6 2 1}$ & $\mathbf{0 . 0 0 0}$ \\
\hline $\begin{array}{l}\text { diminished sense of personal } \\
\text { accomplishment*/emotions- } \\
\text { concentrated stress coping strategies }\end{array}$ & 47 & -0.261 & -1.816 & 0.076 \\
\hline $\begin{array}{l}\text { diminished sense of personal } \\
\text { accomplishment*/avoidance- } \\
\text { concentrated stress coping strategies }\end{array}$ & 47 & 0.023 & 0.158 & 0.875 \\
\hline
\end{tabular}

* for variable labeled "diminished sense of personal accomplishment" reverse scale

is used, thus the correlation sign should be changed while interpreting the data and a diminished sense of personal accomplishment with stress coping strategy that is concentration on task. In other comparisons, Spearman's rank does not show vital statistical positive correlation between studied variable among pedagogy students.

\section{DISCUSSION}

Emotional exhaustion exists on the same level among all examined students which is the basis and the first stage of job burnout. Depersonalization is significantly on the higher level among pedagogy students. However, a diminished sense of personal accomplishment is on the higher level among medical and nursing students than among pedagogy students. As the main source of future job burnout students indicate academic professors' negligent atti-tude, no free time, too much to learn and too many duties. Pedagogy students emphasise the existence of too much theory and not enough practice, disappointment by their academic program and reality, which does not meet their expectations. On the other hand, nursing students stress too much practice and unpleasant experience of their practice. This is partially confirmed by results from a previous study carried out in 2005 in Kraków [7] among 84 nursing and medical students, which showed that emotional burden experienced during practice, low level of empathy and the awareness of low future income may result in job burnout.

Similar study regarding the frequency of job burnout and factors causing it was con-ducted in the USA [8] among 249 medical students. The study showed that for medical stu-dents the greatest stress stimulant were grades and unclear future. The study proved that job burnout is developing gradually during medical education while high level of support received and low stress level decrease job burnout significantly.

A study about stress and job burnout carried out among nursing students in Hong Kong [9] confirmed that a reason for stress, job burnout and mental problems was neurotic personality combined with concentration on emotions as stress coping strategy.

According to results from the study the main reason for stress during students' aca-demic education were for $44.7 \%$ of students exams and tests, for $21.3 \%$ professors' neglecting attitude and for $7.8 \%$ requirements which are beyond students' capacity. On the other hand, the main reasons for stress apart from academic education were for $14.9 \%$ of students family problems and for $8.5 \%$ - the financial problems. The results are equal to earlier study about reasons for stress among 117 part-time and full-time nursing and public health students in Poznan [10], where the main reasons for stress among full-time students were education $(90.3 \%)$, family and personal problems (54.8\%) and one's financial situation (38.7\%). Part-time students claimed that education was the most stressful factor (58.1\%); then they indicated their job (51.2\%), daily family and personal duties which were difficult to combine with job and also financial problems $(44.2 \%)$ and family and personal problems $(41.0 \%)$.

The results from the study confirmed pervious attempt to assess students' lifestyle at Silesian universities [11]. The main reasons for stress among $82.3 \%$ of students were 
exams and tests, among 34.2\% too much to learn, among $32.9 \%$ of students - no free time, and among $14 \%$ of them personal and family problems.

A similar study carried out among nursing students in Iran [12] showed that reasons for stress were finding new friends $(76.2 \%)$, new responsibilities $(72.1 \%)$, increased level of work during studies $(66.9 \%)$, starting education $(65.8 \%)$, finding yourself in new situations $(64.2 \%)$ and long waiting in queues $(60.4 \%)$. Among stress coping strategies, which involve activity the most common were attempts to find out how to cope with problems $(66.4 \%)$ and attempts to improve oneself $(64.5 \%)$.

To conclude, it might be said that there is a relation between many ineffective stress coping strategies and high level of job burnout, what means that employing effective stress coping strategies may prevent job burnout in some way. Consequently, the obtained results may be used to make students, academic professors and people responsible for education aware how important it is in education to teach students how to prevent job burnout and cope effectively with stressing situations occurring during their academic education. It is extremely relevant in the light of American comparative study about job burnout among medical students, which showed that the risk of job burnout occurs two times more often between the $3 \mathrm{rd}$ and the 6 th year of medical studies [13] and depends on personal life events and academic program [14]. In addition, a study conducted among nursing students in Scotland [15] showed that stress and job burnout were increasing during every year of their academic education.

\section{CONCLUSIONS}

The study carried out among medical, nursing and pedagogy students shows that:

1. The majority of medical and nursing students employ concentration on task as a stress coping strategy, but pedagogy students employ both concentration on emotions and on task as their stress coping strategies.

2. Obtained results do not confirm any relation between job burnout and academic major.

3. The study confirms that there is a relation between job burnout and stress coping strategies among students of selected academic majors. The higher level of emotional exhaustion, the more often stress coping strategy that is concentration on emotions is used. The same statement is declared in case of depersonalization and stress coping strategy that involves concentration on emotions, and opposite correlation between a diminished sense of personal accomplishment and stress coping strategy that concen-trates on task.

\section{REFERENCES}

1. Maslach C, Schaufeli WB, Leiter MP. Job burnout. Ann Rev Psychol. 2001;52:397-422.

2. Tucholska S. Christiny Maslach koncepcja wypalenia zawodowego: etapy rozwoju. Przegl Psych. 2001;44(3):301-17.

3. Lazarus RS. Psychological stress and the coping process. New York: McGraw-Hill; 1966.

4. Bargiel-Matusiewicz K, Podbielski Z, Klasik A. Współczesne rozumienie stresu. Wiad Lek. 2004;LVII(3-4):188-92.

5. Endler WS, Parker DA. Multidimensional assessment of coping: a critical evaluation. J Personal Soc Psychol. 1990;58(5):844-54.

6. Jelonkiewicz I, Kosińska-Dec K. Poczucie koherencji a style radzenia sobie ze stresem: empiryczna analiza kierunku zależności. Przegl Psych. 2001;44(3):337-47.

7. Wilczek-Rużyczka E, Repka I. Professional burnout versus empathy in nursing and medical students. Zdr Publ. 2006;116(1):61-4.

8. Santen SA, Holt DB, Kemp JD, Hemphill RR. Burnout in Medical Students: Examining the Prevalence and Associated Factors. Southern Med Assoc. 2010;103(8):758-63.

9. Watson R, Deary I, Thompson D, Li G. A study of stress and burnout in nursing students in Hong Kong: A questionnaire survey. Int J Nurs Stud. 2008;45:1534-42.

10. Rosołowska J. Przyczyny stresu u studentów wydziału Nauk o Zdrowiu Akademii Medycznej w Poznaniu. Piel Poł. 2003;1(15):82-7.

11. Ordys D, Eszyk J. Próba oceny stylu życia młodzieży studenckiej śląskich uczelni. Annales UMCS Lublin, Polonia Sectio D. 2003;LVIII (Suppl. XIII) 177:404-9.

12. Seyedfatemi N, Tafreshi M, Hagani H. Experienced stressors and coping strategies among Iranian nursing students. BMC Nursing. 2007;6:11.

13. Galan F, Sanmartin A, Polo J, Giner L. Burnout risk in medical students in Spain using the Maslach Burnout Inventory-Student Survey. Int Arch Occup Environ Health. 2011;84:453-9.

14. Dyrbye LN, Thomas MR, Huntington JL, et al. Personal Life Events and Medical Student Burnout: A Multicenter Study. Acad Med. 2006;81(4): 374-84.

15. Deary IJ, Watson R, Hogston R. A longitudinal cohort study of burnout and attrition in nursing students. Blackwell Publishing Ltd. J Adv Nurs. 2003;43(1):71-81.

\section{Informacje o Autorkach}

Prof. nadzw. dr hab. EwA WILCZEK-RuŻYCZKA - kierownik, Katedra Psychologii Zdrowia, Wydział Psychologii i Nauk Humanistycznych, Krakowska Akademia im. Andrzeja Frycza Modrzewskiego; mgr Magdalena JABŁeKA - Oddział Leczenia Zaburzeń Osobowości i Nerwic, Szpital Specjalistyczny im. dr Józefa Babińskiego w Krakowie.

\section{Corresponding Author}

Ewa Wilczek-Rużyczka

Katedra Psychologii Zdrowia,

Wydział Psychologii i Nauk Humanistycznych,

Krakowska Akademia im. Andrzeja Frycza Modrzewskiego

ul. Gustawa Herlinga-Grudzińskiego 1, 30-705 Kraków

E-mail: ewaroz0@poczta.onet.pl 